\title{
«I OFTEN THOUGHT IF IT COULD NOT BE DISSOLVED, IT COULD ONLY WITH LIFE BE EXTIRPATED»: A TRANSLEMIC ANALYSIS AND SPANISH TRANSLATION OF FRANCES BURNEY'S LETTER FROM FRANCES BURNEY TO HER SISTER ESTHER ABOUT HER MASTECTOMY WITHOUT ANAESTHETIC, $1812^{1}$
}

\author{
«A MENUDO PENSABA QUE SÓlO DESAPARECERÍA A \\ NO SER QUE ME QUITASEN LA VIDA»: UN ANÁLISIS \\ TRANSLÉMICO DE CARTA DE FRANCES BURNEY A \\ SU HERMANA ESTHER SOBRE SU MASTECTOMÍA SIN \\ ANESTESIA, 1812
}

Author / Autora:

Carmen María Fernández Rodríguez

EOI A Coruña/ University of A Coruña,

A Coruña, Spain

carmen.mariafernandez@edu.xunta.com

https://orcid.org/0000-0001-5165-6083

Submitted / Recibido: 30/09/2020

Accepted / Aceptado: 05/02/2021

To cite this article / Para citar este artículo: Fernández Rodríguez, C. M. (2021). «I often thought if it could not be dissolved, it could only with life be extirpated»: a translemic analysis and Spanish translation of Frances Burney's Letter from Frances Burney to her sister Esther about her mastectomy without anaesthetic, 1812. Feminismo/s, 39, 59-95. https://doi.org/10.14198/fem.2022.39.03

\section{Licence / Licencia:}

This work is licensed under a Creative Commons Attribution 4.0 International.

\section{(c) (i)}

(C) Carmen María Fernández Rodríguez

\section{Carmen María FERNÁNDEZ RODRÍGUEZ}

\section{Abstract}

Frances Burney (1752-1840) was one of the most influential eighteenth-century British novelists. Apart from the novel, Burney also cultivated the theatre and she wrote texts of a marked political nature on the French Revolution, a fact that is not so well- known by the general public. This article is inscribed within the framework of gender studies and the so-called Burney Studies and aims to analyze Letter from Frances Burney to Her Sister

1. This essay is part of the outcome of the University of A Coruña Research Network «Rede de Lingua e Literatura Inglesa e Identidade III» ED431D2017/17. 
«I often thought if it could not be dissolved, it could only with life be extirpated»: a translemic analysis and Spanish translation of Frances Burney's Letter from Frances Burney to her sister Esther about her mastectomy without anaesthetic, 1812

Esther About her Mastectomy Without Anaesthetic, 1812. By its subject, the document is an account of current interest for both medicine and feminism. Here Letter Here Letter is studied from the perspective of translation studies, specifically taking Itamar Even-Zohar's theory of literary polisystems and various translation strategies as a methodological reference. We will examine the configuration of the key elements of Even-Zohar's approach and various translation strategies as a methodological reference in this text which we will approach translation studies as a pathography, insisting on the identification between female subject and writing, Burney's courage in confronting the disease and the particular relationship she establishes with the participants in the story and the impact that disease has on those around and helping her. Finally, the Spanish translation of Letter is offered, so Spanish-speaking readers have access to this document recently digitized by The British Library. Letter is a chronicle of pain, but also of courage and a real lesson in the intimate relationship between women and writing that was always so important to Burney. This study also means a re-vision of the writer that is far from what we could have until now.

Keywords: Frances Burney; Translation studies; English literature; Cancer; Gender studies.

\section{Resumen}

Frances Burney (1752-1840) fue una de las novelistas británicas más influyentes en el panorama literario de finales del siglo XVIII, pero también cultivó el teatro y escribió textos de marcado carácter político sobre la Revolución Francesa, parcelas que no son tan conocidas por el público. Este artículo se enmarca dentro de los estudios de género y los llamados Burney Studies y pretende analizar la Carta de Frances Burney a su hermana Esther sobre su mastectomía sin anestesia, 1812. Por su temática, el documento supone un relato de interés actual para la medicina y el feminismo. Aquí se analiza Carta desde los estudios de traducción, concretamente tomando como referencia metodológica a Itamar Even-Zohar y diversas estrategias de traducción. Examinaremos la configuración de los elementos clave de la teoría de los polisistemas literarios en este texto al que nos acercaremos como patografía, incidiendo en la identificación entre sujeto femenino y escritura, la valentía de Burney al enfrentarse a la enfermedad, la particular relación que ella establece con los participantes del relato y el impacto que tiene la enfermedad en aquellos que la rodean y ayudan. Finalmente se ofrece la traducción al castellano de Carta para que los lectores hispanohablantes tengan acceso a este documento recientemente digitalizado por la British Library. Carta es una crónica del dolor, pero también de valentía y una auténtica lección sobre la relación íntima entre mujer y escritura que siempre fue tan importante para Burney. Este estudio supone también una re-visión de la escritora que dista bastante de la que podríamos tener hasta ahora. 
«I often thought if it could not be dissolved, it could only with life be extirpated»: a translemic analysis and Spanish translation of Frances Burney's Letter from Frances Burney to her sister Esther about her mastectomy without anaesthetic, 1812

Palabras clave: Frances Burney; estudios de traducción; literatura inglesa; cáncer; estudios de género.

\section{INTRODUCTION}

The importance of Frances Burney (1752-1840) in late eighteenth-century English literature has been highlighted from various perspectives: as a novelist, a satirist of manners, a diarist and a chronicler of the situation of women in the pre-Victorian era. From 1975 onwards, research on Burney has attracted the interest of feminist researchers who started to examine the portrait of female difficulties in Burney's novels and her particular way of attacking society. Thus, eminent researchers — such as Elaine Showalter (1977), Dale Spender (1986), Sandra M. Gilbert and Susan Gubar (1984) and Ellen Moers (1977) — have noticed her work. In recent years, research on Burney has gained strength thanks to the interest in her dramatic work, studies on Burney's translation into other cultures, and the comparison between the author and her contemporaries. The role of The Burney Centre and The Burney Society in promoting all current research on the Burneys and Peter Sabor's work as director of the center and great expert and editor of several Burney works cannot be ignored either, and literary studies certainly have to pay attention to this prolific author with such an interesting life. A witness of the socioeconomic and cultural changes associated with the Industrial Revolution, Burney contemplated the events of the French Revolution from England and then she lived in France during the Napoleonic Wars because of her family situation. All of Burney's writings reveal a good deal of social sensibility and her self-awareness as an author. This article bears in mind feminism and translation studies to rediscover Letter from Frances Burney to Her Sister Esther About her Mastectomy Without Anaesthetic, 1812 (Letter henceforth). Burney's work will be analyzed applying Even-Zohar's polysystem theory (PT) to the text considering the translation procedures that have been adopted in the Spanish target text (TT). 
«I often thought if it could not be dissolved, it could only with life be extirpated»: a translemic analysis and Spanish translation of Frances Burney's Letter from Frances Burney to her sister Esther about her mastectomy without anaesthetic, 1812

\section{THEORETICAL CONCEPTS}

In the 1970s Israeli culture scholar Itamar Even-Zohar developed the PT which accounted for the complexity of culture within a single community and between communities. In Even-Zohar's terms, the literary system is seen as «[t]he network of relations that is hypothesized to obtain between a number of activities called literary, and consequently these activities themselves observed via that network» (1990, p. 28) with six distinct elements, which depend on each other and are dynamically related:

[...] a CONSUMER may «consume» a PRODUCT produced by a PRODUCER, but in order for the "product» (such as «text») to be generated, a common REPERTOIRE must exist, whose usability is determined by some INSTITUTION. A MARKET must exist where such a good can be transmitted (Even-Zohar, 1990, p. 34).

Three points are paramount to understand the PT where none of the six elements can exist in isolation and many nuisances and strata can be found. Firstly, the value of the institutions, the market and the repertoire is firmly linked to the historical moment and the market generates the space for the implementation of the repertoire through products to the point that it sometimes determines the existence of them. Thus, Burney wrote for a female audience and her works sold well: Evelina earned her 20 guineas, but its author earned 250 pounds for Cecilia and 1000 pounds for Camilla plus 1000 additional pounds from subscription sales. Secondly, the institutions always work towards canonization, no matter if the products that they intend to canonize may be radically different. Institutions set standards, or the set of precepts and models that determine how the repertoire should be used and compliance with these standards allows certain products to remain at the heart of the system, legitimized and backed by agents, as it happened to Burney's work which was almost always supported. Thirdly, the repertoire tends to be equated with the artistic tradition possessed by a polysystem: institutions and standards favour the use of certain parts of the repertoire, while they penalize or marginalize others for different reasons.

Even-Zohar used his scheme to examine translation, laws of interference and the position of translated literature in the literary system. If we apply Even-Zohar's analysis here to contrast the source text (ST) and the TT, some 
«I often thought if it could not be dissolved, it could only with life be extirpated»: a translemic analysis and Spanish translation of Frances Burney's Letter from Frances Burney to her sister Esther about her mastectomy without anaesthetic, 1812

remarkable differences arise. In the first case, what we find is that Burney (a producer) composed Letter (the product) addressed to her sister Esther and the Burney family who stand for the consumers. Letter has to be related to the repertoire of the pathography and the family letter, which also applies to the institution since Letter was not intended for publication. Likewise, the author had no market in mind. As Burney simply wrote this document to inform Esther about her situation, there was no economic benefit from the composition of Letter and we have a restricted female audience.

An examination of the twenty-first century translation reveals another panorama affecting the consumers and the market. Despite the laudable effort of some publishing houses like D'Epoca or Alba Clásica, to name just a few, eighteenth-century English literature by women is not popular in Spain. In Burney's case, the situation is relatively good. Two dissertation theses discussed her oeuvre (Aragón, 1997; Fernández Rodríguez, 2007) and we have some studies on her work and the translations of Evelina (Fernández Rodríguez, 2018) and of two comedies (Burney, 2017) into Spanish as well.

There are several reasons to adopt Even-Zohar's approach. I follow Susan Bassnett's argument that Even-Zohar prepared the ground for a cultural turn because thanks to the PT some issues related principally to questions of literary history and the fortune of translated texts in the receiving culture finally came to occupy a prominent position in literary research. More specifically, Bassnett (1997) highlights that the works by women had become as invisible as the importance of translation was ignored. Still, comparing and reassessing two periods of literary history involves rethinking our assumptions about what constitutes significant literature. In both cases, a parallel process of questioning established norms takes place, and this process can be considered a definite cultural turn (Basnett, 1997, p. 16). The combination of the PT and gender studies is justified in this article bearing in mind that literary history is subject to change and that Even-Zohar has always striven to offer a global vision of literature which does not ignore the periphery and marginalized texts. Besides, his analysis opens the path not only to translation studies but also to postcolonial studies and gender studies where Burney undoubtedly shines. 
«I often thought if it could not be dissolved, it could only with life be extirpated»: a translemic analysis and Spanish translation of Frances Burney's Letter from Frances Burney to her sister Esther about her mastectomy without anaesthetic, 1812

\section{LETTER AND THE POLYSYTEM THEORY}

\subsection{The producer and her work: Frances Burney's passion for writing}

Like the rest of the elements of the literary system, the producer does not act alone: groups, social communities are engaged in production and they relate to each other just as their potential consumers do. They form part of the literary institution and the market. These grouplike activity has to be seriously considered though «ephemeral or secondary modes of organization, the conditions and constraints of the world of literary producers are persistently either ignored or relegated to 'sociologists', even by those for whom the individual producer is inevitable, though hardly desirable» (EvenZohar, 1990, pp. 35-36). Thus, Burney has to be contextualized within the emergence of women writers at the end of the eighteenth century and the existence of powerful female clubs, for example the Bluestockings sponsored by literary patrons, like Hester Lynch Thrale (1741-1821) —one of Burney's acquaintances-, or Lady Elizabeth Montagu (1718-1800).

Burney was the daughter of the musicologist Charles Burney (17261814) and was born into an important family of musicians, writers, painters and explorers with important contacts. Her mother died when the girl was just ten and Burney was misunderstood by her stepmother, Elizabeth Allen (1728-1796). Burney's diaries reflect a shy, highly observant girl who often felt apart from others. Burney was always closely attached to writing and even wrote a diary addressed to «Nobody», to whom she confessed her hopes and fears (Doody, 1988, p. 41). Because writing was seen as a natural impulse which had to be suppressed, it was a source of conflict with Dr. Burney: «The true cause of her concern and guilt seems to be the independence of the compulsion to write, to engage in a private and self-sustaining activity» (Doody, 1988, p. 37). Evelina, the novel that would captivate London readers in 1778, dealt with a young countryside girl arriving in London and it brought the novelty of being an epistolary novel published anonymously and told from a woman's point of view. It was also preceded by a preface in which the novel was defended as a genre when novelists, and, above all, women who wrote novels, were disapproved of. Thanks to the success of Evelina, Burney met great writers and aristocrats — such as Dr. Samuel Johnson (1709-1784), Edmund Burke (1729-1797), Sir Joshua Reynolds (1723-1792), 
«I often thought if it could not be dissolved, it could only with life be extirpated»: a translemic analysis and Spanish translation of Frances Burney's Letter from Frances Burney to her sister Esther about her mastectomy without anaesthetic, 1812

or Fulke Greville (1717-1806) —, and she continued her prosperous career with Cecilia (1782), Camilla (1796) and The Wanderer (1815).

No matter from which perspective they are regarded, Burney's works constitute a very rich corpus; they were composed at different times and reflect Burney's frustrations, illusions and experiences. Apart from novels, Burney also penned the essay Brief Reflections Relative to the Emigrant French Clergy (1793), Memoirs of Dr. Charles Burney (1832) and several comedies (The Witlings 1779, Love and Fashion 1798, A Busy Day 1800-1802 and The Woman Hater 1802) and tragedies (Edwy and Elgiva 1788-1789, Hubert de Vere, The Siege of Pevensey and Elberta). Encouraged by two family friends, Arthur Murphy and Richard B. Sheridan, the author embarked on the composition of The Witlings. Nevertheless, she was warned that a young woman should not venture to write for the stage because neither actresses nor playwrights were respected and the theatre involved public exposure and carte blanche to criticize the most powerful. Eighteenth-century scholars, like Peter Sabor, now consider that, if performed, Burney's comedies would have changed the history of English theatre due to their social satire and feminist message (Clark, 2013, p. 148). Nonetheless, the author did not give up: many themes and characters skillfully migrated to her second novel, Cecilia, just as her tragedies are directly related to the loneliness and misunderstandings she faced during her time at the Court of George III in Windsor when she was offered a position as Keeper of the Robes to Queen Charlotte.

After this five-year period suffering misery and oppression, Burney began frequenting the circle of William and Frederica Locke, who offered protection to a group of French émigrés in London. Mme. De Staël (17661817) was among them and also a refined officer of the French army named Alexandre Jean Baptiste Piochard d'Arblay (1754-1818), who would become Burney's husband against Dr. Burney's disapproval of her daughter marrying a French and Catholic émigré. Mme. d'Arblay then lived one of the happiest periods of her life, culminating in her motherhood at the age of 42 . The couple had only one son, Alexander, and the political situation would lead them to move to France, where French-born aristocrat d'Arblay planned to find a job, as the family lived on the pension that the writer received from her stay at Court and the income from her novels. When she arrived in France, Burney frequented the best circles in Paris and she came to be received by 
«I often thought if it could not be dissolved, it could only with life be extirpated»: a translemic analysis and Spanish translation of Frances Burney's Letter from Frances Burney to her sister Esther about her mastectomy without anaesthetic, 1812

King Louis XVIII, the Duchess of Angoulême and the Tsar. Scarcely had Burney been living in France for six years when the event examined in this article took place in 1810 .

\subsection{The product: Letter within Burney's literary production}

In a macrotextual analysis, Letter corresponds with a first person narrative. The point of view is Burney's and it is intensely subjective. She concentrates on her suffering and even declares that she has problems with processing events. It seems that the pain she had been suffering in her right breast for some months became so unbearable that she could not lift her arm. Burney consulted female friends and doctors, who diagnosed her condition as breast cancer and a mastectomy was recommended. Burney found it very hard to believe that what she was feeling could kill her. Finally, as the pain increased, Burney accepted the decision of her doctors, but she faced her operation full of fears and apprehension. The nature of Burney's tumor remains a mystery. She still lived for twenty-nine years after the operation and would later take care of her husband in his final hours when he becomes ill and dies of cancer in 1818 (Wiltshire, 1993b). Yet, the letter reflects Burney's intimate and intense relationship with writing as part of her identity and rarely do we encounter such a moving testimony of feminine pain capable of transcending eras and cultures. Here we find an authentic Burney who feels overwhelmed by nightmarish events and is a narrator who does not resort to irony. For feminist critic Julia Epstein,

[s] he struggled not to struggle against her physicians during that ordeal very much as she had struggled not to write as a young woman. In the mastectomy letter, Burney encodes a series of contradictions into her writing: self-control and violence; acceptance and protest; passivity and rebellion» (1989, p. 33).

Of all Burney's texts - and we include here Camilla's delirium in the homonymous novel-Letter is where Héléne Cixous's ideas (1976) are best reflected: Burney needs to develop the female écriture by writing her body; she wants to build her own writing which counteracts the patriarchal operation of doctors. 
«I often thought if it could not be dissolved, it could only with life be extirpated»: a translemic analysis and Spanish translation of Frances Burney's Letter from Frances Burney to her sister Esther about her mastectomy without anaesthetic, 1812

The text, which was written at intervals, can be divided into five parts: 1) motivation of the letter, 2) discovery of the problem and reluctance to be treated by doctors, 3) preparations for the operation, 4) operation itself, 5) coda. It is surrounded by adjacent texts, so there is a complementary text of the same operation narrated in the notes of Dr. Larrey's pupil, which Epstein reproduces in her article:

Madame D'Arblay a subi hier à 3 heures 3/4 L'extirpation d'une tumeur Cancéreuse du Volume du poing et adhérente au muscle grand Pectorale e Développée dans le sein droit.

L'opération faite par Mr. Le Baron Larrey, assisté du Professeur Dubois $\&$ des Docteurs Moreau, Ribes, [Hereau] \& Aumont, a été très doulereuse $\&$ supportée avec un grand Courage.

La Squirre a présenté dans son centre un Commencement de dégénérescense Cancéreuse; mais toutes ses racines ont été enlevées \& dans aucun Cas une opération aussi grâve n'a offert plus d'espoir de succès-

L'extrême sensibilité de la malade a rendu très violent le spasme qui a suivi l'opération, il n'a diminué que pendant la nuit et par l'emploi des potions calmantes anti-spasmodiques-

De 2 à 3 heures du matin madame a éprouvé quelques instans de sommeil très agitté à 4 des douleurs de tête des nausées et des vomissemens lui ont procuré beaucoup de fatigue $\&$ de faiblesse. Ces accidents que le Docteur Larrey avait indiqués comme devant terminer le spasme ont en effet été suivis de calme \& de deux heures de sommeil paisible-

À 10 heures la malade est étonnée du bien être qu'elle éprouve $-\mathrm{Mr}$ Larrey la trouve sans fièvre, la douleur est presque nulle dans la plaie, l'appareil n'offre pas même la transsudation sanguine ordinaire que l'exacte ligature des artères a empêché.

On prescrit dans la journée quelques bouillons des crèmes de riz- de la gelée de Viandes.

Pour boisson l'eau de poulet, \& la décoction d’orge gommée \& acidulée avec de citron, alternativement..

Ce soir une Médicine avec la décoction de graine de lin \& de têtes de pavots $^{2}$ (qtd. 1986, pp. 150-1).

2. Yesterday at 3:45, Madame d'Arblay underwent the removal of a cancerous tumor the size of a fist which had developed in the right breast adherent to the pectoralis major muscle.

The operation performed by the Baron Larrey, assisted by Professor Dubois and Doctors Moreau, Ribes, [Hereau] and Aumont, was very painful and was tolerated with great courage:

Feminismo/s 39, January 2022, 59-95 
«I often thought if it could not be dissolved, it could only with life be extirpated»: a translemic analysis and Spanish translation of Frances Burney's Letter from Frances Burney to her sister Esther about her mastectomy without anaesthetic, 1812

The motivation of the letter arises from the political situation of the moment. Residing in France from 1802 to 1812, Burney has not written to her family for a long time from a country then at war with England. For doctors, having in their hands a patient like Burney was a political act in that it meant not only saving a foreigner from an enemy country, but also saving a woman writer who was shown the greatest literary respect in France (Fernández Rodríguez, 2018). Letter is Burney's first attempt to smuggle a text into British territory. She would try again with her last novel, The Wanderer, which traveled with her back to England later, in August 1812. As Burney states in its dedication to Dr. Burney, the manuscript passed customs after she had assured officers that it was not a political text while it was the author's most vindicating and openly feminist novel.

Letter is envisioned in feminine terms and there is a clear feminist message behind the writing. It is a document produced by and for women and a copy of the letter is accompanied by a more than revealing note: «Breast operation/Respect this/\& beware not to injure it», which makes it clear that body and writing were intimately linked to Burney. As so often throughout her life, the author is embodied in a text. After battling against a painful inner conflict, Burney finally decides to confess how she feels and addresses her sister confidante, Esther, warning her not to make the text public at the

The scirrhus [hardened tumor] showed the beginnings of a cancerous degeneration in its center; but all of his roots were removed and no case of such a serious operation has offered greater hope of success-

The patient's extreme sensitivity made the spasm which followed the operation very violent, it did not diminish until during the night and with the administration of calming anti-spasmodic potions.

From 2 to 3 o'clock in the morning madame experienced some moments of agitated sleep at 4 headaches attacks of nausea and vomiting made her quite tired and weak. These events, which Dr. Larrey had indicated would necessarily end the spasm were indeed followed by a calm \& by two hours of peaceful sleep.

At 10 the patient was surprised at the well-being she felt-Mr Larrey found her without fever, the pain almost nonexistent in the wound, the precise ligature of the arteries had prevented even the ordinary transsudation of blood through the dressing.

We prescribe during the day boiled rice pudding-meat jelly.

To drink chicken broth, and a potion of barley gummed and acidified with lemon, alternately.

This evening a medication with a portion of linseed and poppy-head (Epstein's translation). 
«I often thought if it could not be dissolved, it could only with life be extirpated»: a translemic analysis and Spanish translation of Frances Burney's Letter from Frances Burney to her sister Esther about her mastectomy without anaesthetic, 1812

same time that she feels the need to share it to serve as a warning to other women in the family.

\subsection{The consumer and the institution: the Burney family}

Even-Zohar (1990) points out that in the literary system there are single consumers as well as a group which is commonly called the public (p. 37). Letter is certainly addressed to a private consumer, Esther, but Burney is totally aware of the potential of her product and of the text type that she uses: the pathography, which is intimately related to her experience as a sick person. According to Marcy Jane Knopf-Newman, a pathography transcends the author's private terrain and has the potential to transform the public sphere by encouraging political action (2004, p. 65), which is precisely what Burney intended to do with each of her writings. Despite her effort to capture her trauma in writing, she experiences some urgency to communicate her story, as highlighted before. In this sense, Thomas Couser argues that disease narratives simultaneously reflect an impulse for self-exploration and the desire to serve those in the same condition (1997, p. 15), so the consumer is inevitably in Burney's mind.

The dialogue established with her interlocutor contributes to Burney's generating her own truth. Without describing, Burney has to interpret signs of what is going on around her by performing an exegesis of male silences, conversations behind one's back, facial expressions and confinement in adjacent rooms. Elizabeth Kuipers, who discusses breast cancer in the work of Mary Astell, Maria Edgeworth and Burney, understands that the latter finally confirms the authority of the female community despite attempts by medical discourse to silence women's voices (2014, p. 198).

As a matter of fact, Burney's vision of doctors is very unstable. On the one hand, they oppose the women around Burney who are always seen positively. Sexually their opponents, the doctors represent the patriarchy who judge and condemn. At the same time, there is a humanization of the medical profession. Even though Burney puts herself on the skin of the doctors who value the extent of her evil, they have to perform the mastectomy and announce future pain. Here the operation is again compared to giving birth, and interestingly, towards the end of the story, Burney explains that it has 
«I often thought if it could not be dissolved, it could only with life be extirpated»: a translemic analysis and Spanish translation of Frances Burney's Letter from Frances Burney to her sister Esther about her mastectomy without anaesthetic, 1812

taken her nine months to be able to write her story. Burney never manifests hatred for the tumor, a second child who lives in her. It annoys and worries her, but it is felt as part of herself, as she states, «I often thought if it could not be dissolved, it could only with life be extirpated» (Burney, 2020, p. 5) and the effects of the operation would last in her body and her writing. The author was right-handed: before the operation she complained about the difficulties she had to write and said her pen hurt: «tired of my Pen! Oh tired! tired! oh! should it tire others in the same proportion — alas for poor Messrs. Longman \& Rees! — \& alas for poorer ME!» (Bloom \& Lilian, 1978, p. 163). She then continued to complain, as the weather in England did not favour her recovery and the cancer episode even changed her calligraphy (Epstein, 1989 , pp. 55-56). Before the operation, Burney not only makes a will that she gives to Mr. La Tour Maubourg, but just before the operation leaves a few lines for her husband and Alex despite the difficulties in writing. It seems as if her last breath even had to be translated into writing.

The institution guarantees the maintenance of literature as a socio-cultural activity (Even-Zohar, 1990, p. 37). As Fernández Rodríguez points out in the introduction to the Spanish translation of Spanish comedies, it is worth noticing that Burney was always respected by the British institution and enjoyed critical support until the end of her career (Fernández, 2017, pp. 16-26), when Burney's neutrality towards France was not accepted and Burney's claims in the dedication of her latest novel were simply regarded as an ordeal for British intellectuality:

Nevertheless, truth and my own satisfaction, call upon me to mention, that, in the circle to which, in Paris, I had the honour, habitually, to belong, piety, generally, in practice as well as in theory, held its just pre-eminence; though almost every other society, however cultured, brilliant, and unaffectedly good, of which occasionally I heard, or in which, incidentally, I mixed, commonly considered belief and bigotry as synonymous terms (Burney, 1991, p. 10).

However, Burney was one of Jane Austen's literary mothers; she is considered the true founder of the novel of manners written by women; and the way she subtly eroded patriarchy with satire while she claimed the social role of women at the dawn of the nineteenth century. Not undeservingly, all these points earned her the nickname «The Iron Pen» in the 1980s. Though Letter 
«I often thought if it could not be dissolved, it could only with life be extirpated»: a translemic analysis and Spanish translation of Frances Burney's Letter from Frances Burney to her sister Esther about her mastectomy without anaesthetic, 1812

had no literary impact when it was composed and Burney was not anxious about it, its author knew well who the letter should never reach: Dr. Burney, her eternal censor and the monitor of Burney's career. This warning works as a paratext, as a fictional advertisement in Genette's terms, and delves into the importance of individual history in fighting a disease while advancing ethical work.

\subsection{The repertoire and the pathography}

The repertoire is defined by Even-Zohar as the aggregate of laws and elements that govern the production of texts. Contrary to what might be expected, it is not the repertoire that determines which texts are canonized, but more complex systemic language relations (1990, pp. 17-8). For Even-Zohar, the canon is just the group of survivors of canonization struggles and «the most conspicuous products of certain successfully established models» (1990, p. 19). Neither is the repertoire uniform. On the contrary, it includes several levels and literary repertoires. Thus, if there is a «repertoire», it may represent the shared knowledge necessary for producing a «text» and various other products of the literary system, there is a repertoire for being a «writer» a «reader,» and yet another for «behaving as one should expect from a literary agent» and so on (Even-Zohar, 1990, p. 40).

Letter must be examined as a pathography due to its interest in the body, disease and suffering. Jason Daniel Tougaw (2006) refers to Burney's mastectomy as a special document where science and sensitivity reinforce each other to justify exposing physical and psychological vulnerability; then he summarizes the common attributes of these breast cancer narratives, which are also met in this case:

They rely on the shock of publicizing private bodily details for narrative impetus; they position themselves as socially vital documents, justifying the representation of socially taboo topics; they combine a clinical, pathologizing gaze with a rhetoric of sensibility in order to justify their violations of privacy and to limit the range of emotional responses they elicit; and they position their narratives as therapeutics documents, whose aim is to intervene in a pathological sequence of events and steer it towards a healthy (and moral) resolution (p. 64). 
«I often thought if it could not be dissolved, it could only with life be extirpated»: a translemic analysis and Spanish translation of Frances Burney's Letter from Frances Burney to her sister Esther about her mastectomy without anaesthetic, 1812

Peripheral as it is in Burney's canon, Letter is not at all unknown to Burney's critics and it has been the subject of the study of medicine and literature (Berman, 2010; Cale, 2017; Flood, 2018), especially since the digitization of the letter. Even if its reception has been very diverse, the research by John Wiltshire (1993a, 1993b, 2019) and Julia Epstein (1986, 1989) clearly stands out. In an excellent feminist work published in 1986, Epstein places Burney's text between a medical-surgical treatise and sentimental fiction and demonstrates how surgery and writing inflict pain while healing. After drawing on several examples of violence in Burney's previous three novels, Epstein (1986) analyzes the letter and refers to other authors and works on breast cancer and concludes that Letter «articulates medical reality by overlaying it with the imaginative and dramatic possibilities intrinsic to the aptly named operating theatre, as it is a text that carves a writer's self-representation out of the body's encounter with knife» (p. 162).

Wiltshire (1993a) considers Burney's letter a pathography for the mixture of detail — which already characterized Burney from her diaries- with dramatic interaction, moral dilemma, and criticism of medical practice (p. 11). In addition, from Wiltshire's point of view, the purpose of a pathography also matches that of Burney's letter:

[it] enables the patient to recover themselves as a person, and to develop or vindicate a substantive epistemological perspective. Discharge or relief (which still emanates from a position of inferiority) is less significant than the reclamation of oneself as an authoritative speaking subject (Wiltshire, 1993a, p. 13).

Breast cancer was nothing new in eighteenth-century literature - Maria Edgeworth's Belinda (1801) and Frances Sheridan's The Memoirs of Miss Sidney Bidulph (1761) had already addressed it - but pathographies like Burney's can even acquire a social function now. In his latest book Wiltshire (2019) describes Burney's portrait of the tensions between doctors and patients as evocative of the fear that still surrounds breast cancer and its surgery and he concludes that few pathographies concentrate as much strength as this text (p. 125). If Burney's narrative exercise is an effort to surpass what was lived through writing, then her pathography can be included within autobiography following Anne H. Hawking (2005, p. xix). Furthermore, in Michelle Faubert's recent review of Wiltshire's book in The Burney Letter,

Feminismo/s 39, January 2022, 59-95 
«I often thought if it could not be dissolved, it could only with life be extirpated»: a translemic analysis and Spanish translation of Frances Burney's Letter from Frances Burney to her sister Esther about her mastectomy without anaesthetic, 1812

pathographies are seen as the means to recover a human and emotional response to medical crises: «a perspective that is sometimes forgotten, since medicine in the past few years has 'depersonalized illness', erased the individual sufferer from the health-care experience in the interest of providing objectively handled and scientific — sometimes insensitive-treatment» (2020, p. 11).

Due to the fact that pathographies concentrate on the body, they focus on the producer. In Letter both doctors and Burney compete for authority: no matter how eagerly Burney defends her body against them, she feels weak before professionals who have to stay calm and convey confidence to their patient. In this sense, Letter reveals the difficulties of the medical profession. On some occasions, not many, Burney looks like an object: she notices the loss of intimacy and how her body simply gets out of control. Nor is it a young body, but that of a sixty-year-old woman. Seeing herself without the clothes she dresses with socially reminds her of her sisters, and, when Larrey asks someone to hold her breast, she does it herself and explains where the pain is located. Burney has limits too. Outraged to see so many doctors, she challenges them and rebels, an attitude that is not at all surprising. Her first novel, Evelina, already included a small text aimed at critics in which Burney asked them to be benevolent and reminded them, «you were all, at one time, young writers, and the most skilled veteran of your army could, remembering his first publication, see his terrors renewed and recognize mine» (Burney, 2013, p. 5).

\section{TRANSLATION STRATEGIES}

Following Gideon Toury (1980), a translated text must be poised between the respect for adequacy of the source language and acceptability in the target language, which is one of the main factors determining the formation and formulation of any translation (p. 16). Therefore, the main goal of this translation into Spanish is to preserve the cultural elements of the ST, which corresponds to the adequacy pole, and foreignization, a resistant translation strategy stressing the cultural differences of the ST and exerting pressure on the target culture, and it is exactly the opposite of the domestication of the text (Venuti, 1995, p. 81). The adopted stance is the respect to the French 
«I often thought if it could not be dissolved, it could only with life be extirpated»: a translemic analysis and Spanish translation of Frances Burney's Letter from Frances Burney to her sister Esther about her mastectomy without anaesthetic, 1812

setting with the use of heavy annotation to make some references comprehensible to the Spanish reader. One of the choices I had to make as a translator was precisely whether or not to render into Spanish the many expressions that Burney inserts in French, which are in consonance with the setting of events. French was once a prestigious language in Spain, the equivalent of English now as the world's language. All these expressions are translated into Spanish to keep some linguistic uniformity. Among the Gallicisms used by Burney, there are family names («beau frère» [Burney, 2020, p. 3]), terms with special connotations evoking stylistic elegance («sauvagerie» [Burney, 2020, p. 4]) and direct speech in French when she reproduces conversations with French characters.

As a translator, my point of departure is also Susan Bassnett's idea that the translator is just a reader, an interpreter and (re)writer who offers a unique, subjective interpretation of the ST through what she considers the translated text (2002, p. 83). In this translation, it is assumed that the twenty-first Spanish reader is not necessarily familiar with certain items, so different strategies have been adopted to approach the acceptability pole. One of them is the addition of footnotes functioning as paratexts, which are a transaction area between the author and the audience that encompasses all the verbal productions accompanying a text and guaranteeing its reception and consumption (Genette, 1987, pp. 7-8). These footnotes elaborate on and expand the ST.

The target reader confronts a text where titles have been substituted by Spanish equivalents. «M.» (Monsieur), «Madame/Me», «Dr.» become «señor», «señora» and «doctor» and «M. d'A/ M. d'Ar»—which stand for M. d'Arblay - are translated with the full name to avoid misunderstandings. The only names that have not been rendered into Spanish are proper names bearing in mind that Frances Burney is known as such, and not as «Francisca Burney», for instance. The opposite criterion has been observed with «Tuilleries» (Burney, 2020, p. 3), «Empress» (Burney, 2020, pp. 1, 3) and «Ps Amelia» (Burney, 2020, p. 4).

Perhaps the major achievement of Carta is the very fact of giving twenty-first-century readers access to a text which was a private document and is less known than other texts produced by Burney. Besides, Carta deals with the most commonly occurring cancer in women and the second most 
«I often thought if it could not be dissolved, it could only with life be extirpated»: a translemic analysis and Spanish translation of Frances Burney's Letter from Frances Burney to her sister Esther about her mastectomy without anaesthetic, 1812

common cancer overall. There are neither prunnings nor censorship of the most violent parts, so no gruesome detail of the operation is omitted, even the legal and military vocabulary, which is occasionally used and has been respected here. Another modern trait is that, though Letter does not exhibit any example of dialect, there is a particularly interesting structure which implies decision-taking for any translator. One of Burney's French acquaintances, Mme. Soubiren, is portrayed in the ST as not proficient in English and Burney reproduces the way she addresses her by repeating «ver. vell, Mawm». In Spanish, this has been versioned as «mu bie Siñora», trying to convey the character's incorrect English pronunciation.

One of the consequences of Burney's reluctance to revise her text is that Letter has no paragraph division, which has been added in the Spanish translation to facilitate comprehension. The writer also uses many long hyphens, which can surprise the modern reader and have been replaced by exclamation marks or commas, if possible. Although this feature affects sentence division, it is in consonance with the aim to bring the text closer to the modern reader.

Other microtextual differences are associated with idioms with a cultural meaning. Dr. Larrey looks «pale as ashes» and here a Spanish equivalent has been found in «estaba tan pálido como la cera», which slightly departs from the source text. Similarly, «dead silence» (Burney, 2020, p. 11) has been rendered as «silencio sepulcral» due to the lack of an equivalent in Spanish. Also regarding stock sentences, «The Coast was clear» (Burney, 2020, p. 9) is rendered with an addition and a corresponding Spanish idiom while «To meet the coming blow» (Burney, 2020, p. 6) becomes «para enfrentarme a las dificultades».

Some additions have been necessary to avoid ambiguity. For instance, Burney simply says «my Alexanders» (Burney, 2020, pp. 2, 8) while in Spanish it is specified «Alexandre padre e hijo». On the contrary, in order to avoid redundancies in Spanish, «my particularly intimate friend» (Burney, 2020 , p. 2) was reduced to «mi amiga íntima».

Following Vinay and Darbelnet's list of translation procedures (1995, pp. 31-42), transpositions - or the change of word class- have been used in those instances in which literal translation would render the text inaccurate for a Spanish reader. While most of the times there is an insignificant 
«I often thought if it could not be dissolved, it could only with life be extirpated»: a translemic analysis and Spanish translation of Frances Burney's Letter from Frances Burney to her sister Esther about her mastectomy without anaesthetic, 1812

semantic nuisance, in other cases the transposition is necessary, especially in long complex expressions and inversions: «There is nothing that can be suggested of use or comfort that she omitted» (Burney, 2020, p. 7) is rendered as «me ha prestado todo tipo de servicios y atenciones»; «I would not trust to convulsive fear the sight of the terrible incision» (Burney, 2020, p. 10) turns into «No me atreví a mirar la terrible incisión por el miedo que me agitaba», and «Speechless \& apalled, off went Alex» (Burney, 2020, p. 9) is translated as «Alex se fue tan mudo y asustado que tuvo que sentarse y lloró al cumplir su cometido».

A particular problem when translating Burney is her penchant for using long sentences. In Spanish, shorter structures have been preferred to facilitate comprehension and some linkage has been added to make the relationship between ideas more explicit. ${ }^{3}$ For stylistic purposes, modulations or the change of point of view has been adopted when the literal translation simply made no sense in Spanish. For instance, when Burney refers to Larrey as «Yet this modest man is premier chirurgien de la Garde Imperiale, \& had been lately created a Baron for his eminent services!» (Burney, 2020, p. 5) as «iY

3. M. Larrey has proved one of the worthiest, most disinterested, \& singularly excellent of men, endowed with real Genius in his profession, though with an ignorance of the World \& its usages that induces a naiveté that leads those who do not see him thoroughly to think him not alone simple, but weak.

El señor Larrey ha demostrado ser uno de los hombres más meritorios, menos interesados y más excelentes, dotado con un gran talento en su profesión, aunque no sabe nada de la sociedad y sus costumbres. Esto provoca una inocencia que lleva a que aquellos que no lo conocen lo consideren no sólo como simplón sino también débil. Beside, I must own to you, that those details which were, till just now, quite unknown to me, have almost killed me; \& I am only able to thank God that this more than half Angel has had the Sublime courage to deny herself the comfort I might have afforded her, to spare me, Not the sharing of her excruciating pains, that was impossible, but the witnessing so terrific a Scare, \& perhaps The remorse to have rendered it more tragic. For I don't flatter myself I could have got through it - I must confess. Además, tengo que reconocer que esos detalles que justo hasta ahora eran bastante desconocidos para mí casi me han matado y sólo puedo agradecer a Dios que este más que medio ángel haya tenido el coraje sublime de negarse el consuelo que yo le podría haber aportado con el fin de ahorrarme el no compartir los dolores atroces. Eso era imposible, pero no el ser testigo de algo tan atroz y tal vez el remordimiento de convertirlo en algo más trágico, ya que debo confesar que no presumo de haberlo podido soportar.

Feminismo/s 39, January 2022, 59-95 
«I often thought if it could not be dissolved, it could only with life be extirpated»: a translemic analysis and Spanish translation of Frances Burney's Letter from Frances

Burney to her sister Esther about her mastectomy without anaesthetic, 1812

pensar que este hombre modesto es el primer cirujano de la Guardia Imperial y recientemente le han hecho barón por sus eminentes servicios!», or when she describes how she is placed in bed «How vain, alas, my representation!» (Burney, 2020, p. 11), which is rendered as $«_{i} \mathrm{Oh}$, lo cuento de una forma vanidosa!» or during the operation «I needed no injunctions not to restrain my cries» (Burney, 2020, p. 11) as «[...] nadie me mandó que me callase».

\section{CONCLUSION}

Translating Letter means translating female psychological and physical suffering, which cannot be examined by just translating the text, but by taking into account the complex textual apparatus surrounding this piece of writing. Even-Zohar's theory has helped us to see Burney in global terms and to render it into Spanish as Burney would probably have liked, respecting her Letter and not injuring it. Publishing Letter online has definitely been a praiseworthy enterprise and it has brought a revision of the Burney canon and a further cultural turn. This analysis has indirectly revised Burney's place within the English polysystem since Letter is admittedly more peripheral than other works. Translating the text into Spanish does not only imply giving Spanish-speaking consumers the opportunity to get to know Burney's chronicle of suffering, but, within the restricted field of Burney's translation into Spanish and the Spanish polysystem of translated literature, it implies dismantling the traditional idea that she wrote only feminocentric novels, like Evelina. Besides, should Burney have tried to publish a text like Letter in her lifetime, she would certainly have been attacked by the English institution in terms of its content: no lady could write about such an intimate issue unless by labelling it fiction and losing her reputation as a serious writer. In this regard, in this translation there is no censorship, Letter is presented to the Spanish audience as it is, without deleting parts, preserving the core of the text and unveiling a new Burney. Finally, Carta has an educational and ethical aim and it is addressed to a heterogeneous readership that can access it online now. Burney would like to reach such a broad audience who can respect and identify with her experience as a sick woman. 
«I often thought if it could not be dissolved, it could only with life be extirpated»: a translemic analysis and Spanish translation of Frances Burney's Letter from Frances Burney to her sister Esther about her mastectomy without anaesthetic, 1812

\section{REFERENCES}

Aragón Varó, A. (1997). El problema de la identidad en las novelas de Frances Burney. Universidad de Cádiz.

Bassnett, S. (1997). Culture and Translation. In P. Kuhiwczak \& K. Littau (Eds.), A Companion to Translation Studies (pp. 1-23). Multilingual Matters.

Bassnett, S. (2002). Translation Studies. Routledge. https://doi. org/10.4324/9780203427460

Berman, M. R. (2010). The Dark Ages of Breast Cancer: Mastectomy Without Anesthesia and Survival for 29 years. Medpage Today, 1 October. https:// www.medpagetoday.com/blogs/celebritydiagnosis/22514

Bloom, E. A. \& Lilian D. B. (Eds). (1978). The Journals and Letters of Fanny Burney: Mme. D’Arblay (Vol. VII. 1812-4). Clarendon Press.

Burney, F. (1991). The Wanderer. (Margaret Anne Doody, Robert L. Mack and Peter Sabor, Eds). OUP. Original work published 1814.

Burney, F. (2013). Evelina. Editorial d'Época. Original work published 1778.

Burney, F. (2017). El ridículo ingenio y Un día de mucho apuro. (M.J. LorenzoModia \& C. M. Fernández Rodríguez Eds.). Arcibel editores.

Burney, F (2020). Letter from Frances Burney to her sister Esther about her mastectomy without anaesthetic, 1812. The British Library. Original work published 1812. https://www.bl.uk/collection-items/ letter-from-frances-burney-to-her-sister-esther-about-her-mastectomy

Cale, J. (2017). Fanny Burney and her Mastectomy. Dirty, Sexy History. https:// dirtysexyhistory.com/2017/08/06/fanny-burney-and-her-mastectomy/

Cixous, H. (1976). The Laugh of the Medusa (K. Cohen \& P. Cohen Trans). Signs 1(4), 875-893. https://doi.org/10.1086/493306

Clark, L. J. (2013). Hidden Talents: Women Writers in the Burney Family. In T. Berg \& S. Kane (Eds.), Women, Gender, and Print Culture in EighteenthCentury Britain: Essays in Memory of Betty Rizzo (pp. 145-166). Lehigh University.

Couser, T. (1997). Recovering Bodies: Illness, Disability, and Life Writing. University of Wisconsin Press.

Doody, M. A. (1988). Frances Burney: The Life in the Works. Cambridge University Press.

Epstein, J. (1986). Writing the Unspeakable: Fanny Burney's Mastectomy and the Fictive Body. Representations, 16(Fall), 131-166. https://doi. org/10.2307/2928516 
«I often thought if it could not be dissolved, it could only with life be extirpated»:

a translemic analysis and Spanish translation of Frances Burney's Letter from Frances Burney to her sister Esther about her mastectomy without anaesthetic, 1812

Epstein, J. (1989). The Iron Pen: Frances Burney and the Politics of Women's Writing. Bristol Classical Press.

Even-Zohar, I. (1990). The Literary Polysystem. Poetics Today, 11, 9-46. https:// doi.org/10.2307/1772666

Faubert, M. (2020). Review of Frances Burney and the Doctors. Burney Letter, 26(2) (Fall), 11-12.

Fernández Rodríguez, C. M. (2007). La aportación de Fanny Burney y Maria Edgeworth a la novela inglesa comprendida entre los años 1778-1834. Universidade da Coruña.

Fernández Rodríguez, C. M. (2017). Introduction. El ridículo ingenio y Un día de mucho apuro. (M.J. Lorenzo-Modia \& C. M. Fernández Rodríguez Eds.). Arcibel editores. https://doi.org/10.1177/0013161X17735843

Fernández Rodríguez, C. M. (2018). French Burney: Some Notes on the Early Reception of Frances Burney's Novels in France. Babel, 27, 87-104. https:// doi.org/10.35869/afial.v0i27.326

Fernández Rodríguez, C. M. (2019). Frances Burney in Spain: An Analysis of Two Modern Translations of Evelina. Op.Cit: A Journal of Anglo-American Studies, 8, 47-68.

Flood, A. (2018, June 2). "The evil was profound'»: Fanny Burney letter describes mastectomy in 1812. The Guardian. https://www.theguardian.com/books/2018/jun/22/the-evil-was-profoundfanny-burney-letter-describes-mastectomy-in-1812

Genette, G. (1987). Seuils. Éditions du Seuil.

Gilbert, S. M. \& S. Gubar (1984). The Madwoman in the Attic: the Woman Writer and the Nineteenth-Century Literary Imagination. Yale University Press.

Hawking, A. H. (2005). Reconstructing Illness: Studies in Patography (2nd ed.). Purdue University Press.

Kuipers, E. (2014). Silence Reconsidered: British Literary Women and Breast Cancer. In K. H. Doig \& F. B. Stutzer (Eds.), Women, Gender and Disease in Eighteenth-Century England and France (pp. 183-200). Cambridge Scholar Publishing.

Knopf-Newman, M. J. (2004). Beyond Slash, Burn and Poison: Transforming Breast Cancer Stories into Action. Rutgers University Press.

Moers, E. (1977). Literary Women. The Women's Press.

Showalter, E. (1977). A Literature of Their Own. Princeton UP. 
«I often thought if it could not be dissolved, it could only with life be extirpated»: a translemic analysis and Spanish translation of Frances Burney's Letter from Frances Burney to her sister Esther about her mastectomy without anaesthetic, 1812

Spender, D. (Ed.). (1986). Fanny Burney, Maria Edgeworth, and the Height of the Achievement. In. D. Spender (Ed.), Mothers of the Novel: a Hundred Good Women Writers before Jane Austen (pp. 270-300). Pandora.

Tougaw, J. D. (2006). Strange Cases: the Medical Case History and the British Novel.

Routledge. https://doi.org/10.4324/9780203960011

Toury, G. (1980). In Search of a Theory of Translation. The Porter Institute for Poetics and Semiotics.

Venuti, L. (1995). The Translator's Invisibility: A History of Translation. Routledge. Vinay, J-P. \& Darbelnet, J. (1995). Comparative Stylistics of French and English: A Methodology for Translation (J.C. Sager \& M-H. Jamel Eds. \& Trans). John Benjamins Publishing Company. https://doi.org/10.1075/btl.11

Wiltshire, J. (1993a). Early Nineteenth-Century Pathography: the Case of Frances Burney. Literature and History, 2(2), 9-23. https://doi. org/10.1177/030619739300200203

Wiltshire, J. (1993b). Love Unto Death: Fanny Burney's 'Narrative of the Last Illness and death of General d'Arblay'(1820). Literature and Medicine, 12(2), 215-235. https://doi.org/10.1353/lm.2011.0115

Wiltshire, J. (2019). Frances Burney and the Doctors: Patient Narratives Then and Now. CUP. https://doi.org/10.1017/9781108629690

\section{Carta de Frances Burney a su hermana Esther ${ }^{4}$ sobre su mastectomía sin anestesia, 1812}

Desde París, relato de una terrible operación - 1812

P.S. Le he prometido a mi queridísima Esther un volumen y aquí está. En este momento me encuentro bastante bien y también mis Alexandre padre e hijo. Por lo tanto, lee esta narración como desees y sin emoción porque todo ha terminado felizmente. Te enviaré el resto en cuanto tenga oportunidad.

4. Charles Burney, padre de Frances, se casó dos veces: la primera vez fue con Esther Sleepe (1725-1762), con la que tuvo cinco hijos: Esther (1749-1832), James (17501821), Frances (1752-1840), Susanna (1755-1800), Charles (1757-1817) y Charlotte (1761-1838). Tras la muerte de Esther en 1762, Charles volvió a casarse en 1769 con Elizabeth Allen (1728-1796), con quien tuvo a Richard Thomas (1768-1808) y Sarah Harriet (1772-1844). Esther Burney era la hermana mayor de Frances, quien la consideraba una madre. Se casó con Charles Rousseau Burney (1747-1819). 
«I often thought if it could not be dissolved, it could only with life be extirpated»: a translemic analysis and Spanish translation of Frances Burney's Letter from Frances Burney to her sister Esther about her mastectomy without anaesthetic, 1812

Me abrazo al presente con ganas. ¡Oh! ¡Que nadie pase por esto que podría volver! Aún no he escrito nada.

\section{Marzo.}

\section{2}

Después de tanto tiempo separada de mi queridísimo padre, hermanos, hermanas, sobrinas y compatriotas, quisiera al menos ahorrarles a sus tiernos corazones el sentir alguna pena por mí, excepto la que ya deben sentir inevitablemente por la ausencia de alguien tan cercano a sus primeros y siempre queridos vínculos. Sin embargo, si supiesen por otra persona que he estado muy enferma, dudarían de mi restablecimiento. ¿Y cómo puedo creer que no se enterarán de lo que ha llegado hasta Sevilla en el sur y Constantinopla en el este? Me han mandado mensajes de ambos lugares, pero nada me obligaba a comunicarlo hasta que me enteré de que el señor Boinville se lo había escrito a su esposa sin ningún miramiento porque no sabía que yo no quería que fuese público. Pese a todo, espero que no se haya enterado mi queridísimo padre. Pero mi querida Esther, tú que conoces más el mundo, lo vas a escuchar en breve. A ti te voy a escribir toda la historia estando yo segura de que, desde el momento en que sepas que me ha sucedido algo malo, tu dulce corazón va a estar constantemente ansioso por conocer su dimensión y circunstancias, así como su final.

Más o menos en agosto del año 1810 empecé a sentir un dolorcillo en el pecho que fue en aumento cada semana, pero era más bien pesado que agudo, sin causarme preocupación por sus consecuencias. Por desgracia, ¿qué es la ignorancia? El más comprensivo de los compañeros sí que estaba más preocupado. No mostraba una queja, una mala cara o un movimiento que indicase dolor y él ya albergaba temores desconocidos para mí. Insistió en que me viese un cirujano. Me resistí ante la idea y esperé que los cuidados y mimos fueran suficientes. Así pasaron unos meses, durante los que mi amiga íntima, la señora de Maisonneuve ${ }^{5}$, se unió a la insistencia del

5. Marie-Françoise-Elizabeth Bidault de Maisonneuve (1770-1850), hermana del mejor amigo del señor d'Arblay, Victor de Latour-Maubourg. Era una mujer divorciada de la máxima confianza de Frances. Su hijo, Maxime, era el compañero de juegos del pequeño Alex. 
«I often thought if it could not be dissolved, it could only with life be extirpated»: a translemic analysis and Spanish translation of Frances Burney's Letter from Frances Burney to her sister Esther about her mastectomy without anaesthetic, 1812

señor d'Arblay para que me viese un médico. Pensé que sus temores eran infundados y no conseguía vencer mis escrúpulos. Ahora comparto esta falsa confianza con mi querida Esther, mis hermanas y sobrinas como un aviso en caso de que las asalte una sensación similar. El señor d'Arblay confió su preocupación a otra querida amiga, la señora de Tracy, quien me escribió una larga y elocuente carta sobre el tema que comenzó a provocar sospechas muy desagradables. Siguió una conversación con ella en la que su insistencia y exposición unidas a su larga experiencia como enferma y su desdichada existencia en tal condición se apoderaron de mí y, de la forma más dolorosa y forzada, dejé de poner objeciones y el señor d'Arblay llamó a un doctor... ¿Señor Bourdois? Maria ${ }^{6}$ llorará. No, mi querida Maria, no le ocasionaría esa molestia a tu cuñado. Él no, sino Dr Jouart, el médico de la señorita Potts. No sopesando bien mi testimonio, me dio unos consejos que no sirvieron para nada, al contrario, empeoré y el señor d'Arblay entonces insistió en que me viese el señor Dubois ${ }^{7}$, quien ya me había ayudado y curado en un absceso sobre el que te puede contar Maria, mi queridísima Esther.

El señor Dubois, el médico más importante de Francia, había sido nombrado obstetra de la Emperatriz, ya se alojaba en las Tullerías y trabajaba sin cesar, pero nada podía detener el ardor del señor d'Arblay por obtener su primer consejo. Afortunadamente para el señor d'Arblay, el señor Dubois sentía gran estima por mí de la época en que me había tratado y, cuando se le solicitó a través de un tercero, aprovechó el primer momento libre para verme mientras la Emperatriz iba a dar un paseo.

Ahora empezaba a darme cuenta del peligro. El señor Dubois me dio una receta para un mes, tras el cual me vería y no dijo nada, pero insistió tanto en que estuviese tranquila y no me preocupase, que no podía sospechar que

6. Se refiere a Maria Allen Rishton (1751-1820), hermanastra de Frances, y con la que siempre se llevó muy bien. Maria se fugó con Martin Rishton escandalizando a la familia, como luego también haría Sarah Harriet.

7. Dr. Antoine Dubois era un médico que ya había atendido a Burney en 1807 después de su embarazo, cuando tuvo un absceso. En el momento de la mastectomía era el obstetra de la Emperatriz Maria Luisa de Austria. Había sido profesor de cirugía y de medicina. Le concedieron el título de barón. En 1820 Dubois fue nombrado profesor clínico de la Faculté de Médecine, cargo del que sería relevado en 1822 y restituido en 1829. Pese a haber publicado pocas obras durante su carrera, se le atribuye la mejora de una serie de instrumentos quirúrgicos, incluyendo un fórceps. 
«I often thought if it could not be dissolved, it could only with life be extirpated»: a translemic analysis and Spanish translation of Frances Burney's Letter from Frances Burney to her sister Esther about her mastectomy without anaesthetic, 1812

hubiese motivo para preocuparse. Me alarmé más porque el señor d'Arblay no apareció después. Se habían quedado en la biblioteca y el señor d'Arblay no volvió hasta que yo fui incapaz de soportar el suspense y le pedí que volviese. Él también intentó tranquilizarme, pero sólo con palabras. Su aspecto me dio miedo. Sus rasgos, todo su rostro, mostraban la tristeza más sombría. Así que no tuve mucha dificultad para decirle lo que él intentaba no decirme, que sería necesaria una pequeña operación para evitar males mayores. ¡Ay! mi querida Esther, no tenía valor para esto. El miedo, la repugnancia por miles de razones, además del dolor, casi se apoderaron de mis facultades y durante algún tiempo estuve más confundida y estupefacta que asustada. Sin embargo, el efecto de esta entrevista fue horrible: los dolores se hicieron más frecuentes y violentos y el bulto se hacía más duro. Tomé mi medicina en vano y todos los síntomas se agravaban.

En ese tiempo el señor de Narbonne ${ }^{8}$ le habló al señor d'Arblay de un cirujano muy eminente, el señor Larrey ${ }^{9}$, que había curado de una enfermedad similar a una dama polaca que él conocía y, como a mí me horrorizaba la operación, el señor de Narbonne insistió mucho en recurrir al señor Larrey. Con agradecimiento me agarré a cualquier esperanza y otro amigo del señor d'Arblay me dio el mismo consejo al momento. El señor Barbier Neuville tiene mucha amistad con este señor Larrey, al que le escribió con la mayor insistencia pidiéndole que usase todos los medios para rescatarme de lo que yo más temía. El señor Larrey llegó, aunque no de buena gana y lleno de escrúpulos hacia el señor Dubois. Tampoco me atendió hasta que yo le expliqué por escrito mi terror ante el retraso ocasionado por el cargo actual y el confinamiento del señor Dubois en Palacio y le solicité ser atendida por él. Llegó una respuesta y ahora yo...

8. Se refiere al General francés Louis-Marie-Jacques-Amalric de Narbonne-Lara (17551813). Fue comandante de la Guardia Nacional de Besanzón en 1790, Ministro de Guerra y vivió en Inglaterra, Suiza y Alemania antes de regresar a Francia en 1800. A finales de 1811 se convirtió oficialmente en ayudante de campo de Napoleón, a quien acompañó en la campaña contra Rusia de 1812.

9. Dr. Dominique-Jean Larrey (1766-1842) era un eminente cirujano militar que acompañaba a Napoleón en sus campañas y era famoso por la velocidad con la que realizaba amputaciones en el campo de batalla, como sucedió en Austerlizt. Realizó importantes aportaciones a la literatura médica con Recueil de mémoires de chirurgie (Colección de recuerdos quirúrgicos 1821) y Clinique chirurgicale (Clínica Quirúrgica 1829-1836).

Feminismo/s 39, January 2022, 59-95 
«I often thought if it could not be dissolved, it could only with life be extirpated»: a translemic analysis and Spanish translation of Frances Burney's Letter from Frances Burney to her sister Esther about her mastectomy without anaesthetic, 1812

\section{[al revés y arriba de la carta]}

Mi Esther y todos aquellos que me quieren, mirad la manera de escribirme con compasión.

\section{[cuerpo principal de la carta]}

vivo bajo un nuevo régimen y me animan nuevas esperanzas. El señor Larrey ha demostrado ser uno de los hombres más meritorios, menos interesados y más excelentes, dotado con un gran talento en su profesión, aunque no sabe nada de la sociedad y sus costumbres. Esto provoca una inocencia que lleva a que aquellos que no lo conocen lo consideren no sólo simplón sino también débil. Se equivocan, pero, al dirigir su atención y pensamientos sólo en una dirección, no se percata del resto.

Todas sus indicaciones parecían funcionar, ya que, aunque yo tenía ataques de terrible dolor, eran más cortos y espaciados y me animaba y salía casi a diario y casi a diario recibía en casa a alguna amistad o persona conocida, lo que contrasta con mi habitual esquivez. ¡Y qué amistades he conocido! ¡Qué amistades tan dulces, compasivas y fervientes durante este doloroso período! En fin, estaba mucho mejor y cada síntoma de alarma se reducía. Mi buen señor Larrey estaba encantado, aunque tan ansioso que me obligó a que me examinara el doctor Ribe. Decía que era el primer anatomista de Francia, ya que, por miedo, temía haberse equivocado, llevado por el deseo de salvarme. Maria te contará: yo me oponía a que me viese este famoso anatomista tanto como me había opuesto a que lo hiciese el señor Dubois. Para mí era un proceso odioso, pero me vi forzada a ceder y el señor Ribe confirmó nuestras mejores esperanzas... Ahora, mi queridísima Esther, debo abreviar, pues el asunto que sigue es menos agradable.

Diversas circunstancias, demasiado prolijas para detallarse, se combinaron para contrarrestar mis deseos halagüeños y toda la habilidad y cuidados de mi asiduo y excelente médico. El mayor de estos males fue la muerte, anunciada en un periódico, de mi bella y querida Princesa Amelia ${ }^{10}$,

10. La Princesa Amelia (1783-1810) era la hija menor del rey Jorge III. 
«I often thought if it could not be dissolved, it could only with life be extirpated»: a translemic analysis and Spanish translation of Frances Burney's Letter from Frances Burney to her sister Esther about her mastectomy without anaesthetic, 1812

la enfermedad de su respetable padre y la muerte repentina del señor Lock ${ }^{11}$ al que mi dulce Susana ${ }^{12}$ casi adoraba. Esta terrible tragedia me llegó en unas pocas líneas de Fanny Waddington, cuando yo no sabía nada de su enfermedad ni temía nada ¡Oh, mi Esther! Debo ser breve ya que todavía no estoy tan fuerte como para soportar la pena. El bueno del señor Larrey, cuando vino a verme después del último de estos disgustos, se consternó al ver una evolución tan negativa: «Y entonces, ¿qué ha sucedido?» gritó e inmediata y tristemente anunció su esperanza infructuosa de que el endurecimiento ya hubiese desaparecido. Se volvió a llamar al señor Ribe, pero él simplemente corroboró el terrible dictamen. No obstante, admitieron mis peticiones de futuros exámenes y el hecho de que el tiempo no era propicio para la operación. En este tiempo, todo mi ejercicio anterior, tan útil y agradable, me ocasionaba un terrible dolor al acabar si subía tres pares de escaleras. Por ello, mi compañero más querido me trasladó a La Rue Mirmenil, donde comenzó mi residencia en París hace casi 10 años ¡Casi 10 el próximo mes! ${ }^{13}$. Aquí estamos en el primero (en el primer piso), pero, ;ay! sin efecto ninguno. Sólo he bajado una vez un pequeño tramo y ya albergaba nuevas esperanzas. Llamaron a un médico, el doctor Moreau ${ }^{14}$, para saber si podía recomendar algún nuevo tratamiento, pero el doctor Larrey ya había probado todo. Se hizo una consulta formal a Larrey, Ribe y Moreau y, al final, todos me condenaban a una operación. Estaba tan asustada como decepcionada, ya que el pobre seno no estaba ni más descolorido ni más grande que su sano compañero. Sin embargo, yo sentía el mal tan profundamente, que pensaba que no podría ser extirpado a no ser que se extirpase la vida. Me armé de toda la razón que poseía o podía asumir y les dije que si no veían otra alternativa, no me opondría a su opinión y experiencia. El buen doctor Larrey, que

11. La familia Lock(e) era muy conocida por Frances. William Locke (1732-1810), mecenas de las artes, había comprado una famosa propiedad, Norbury Park, que Frances solía visitar.

12. Susana Burney también era hermana de Burney y su gran confidente. Se casó con el oficial Molesworthy Philips (1755-1832) y vivió varios años en Irlanda, donde su esposo estuvo destinado justo en la época de la Rebelión Irlandesa de 1798.

13. Hay un pequeño error. Los d'Arblay llegaron a Francia en 1802, pero no viven en la capital hasta 1805. Dejarán el país en agosto de 1812.

14. Burney distingue entre Dubois y Larrey, que son «surgeons» (cirujanos) y el resto de médicos que son «physicians» y no están tan especializados.

Feminismo/s 39, January 2022, 59-95 
«I often thought if it could not be dissolved, it could only with life be extirpated»: a translemic analysis and Spanish translation of Frances Burney's Letter from Frances Burney to her sister Esther about her mastectomy without anaesthetic, 1812

durante su larga asistencia se había encariñado conmigo, tenía los ojos llenos de lágrimas. Él temía que el miedo me hiciese oponer resistencia. Propuso volver a llamar al señor Dubois. «No», le dije, «si él no me podía salvar no tengo ninguna otra esperanza en ningún sitio y si debe ser, lo que me falta en valor me lo dará la confianza en mí misma». El buen hombre ahora estaba descontento consigo mismo y declaró que yo debía ser tratada por la más alta y eminente autoridad de su país; «Señora, usted es tan considerada aquí que incluso el público se enfadará si no le ofrecemos toda la ayuda posible», dijo él. ¡Y pensar que este hombre modesto es el primer cirujano de la Guardia Imperial y recientemente le han hecho barón por sus eminentes servicios! Añadió que tal vez el señor Dubois supiese algún remedio gracias a sus extraordinarias habilidades y experiencia. Esto me conquistó rápidamente. «¡Ah! Mándenlo venir! ¡Mándenlo venir!», grité y el doctor Moreau recibió órdenes de consultarle ¡Qué intervalo fue este! Sin embargo, mi pobre señor d'Arblay daba más pena que yo, aunque desconocía la terrible idea que yo había añadido al diagnóstico, pero ¡ay, cuánto sufría y con qué ternura exquisita encontraba consuelo en todo lo que yo tenía que soportar!

Hice todo lo posible por ocultar la situación a mi pobre Alex el máximo tiempo posible. El señor Dubois se comportó extremadamente bien. Ningún resentimiento se enfrentó al interés que había manifestado por mi bienestar y su conducta fue caballerosa y generosa. Aunque era difícil verle, él reservó el primer día que pudo para consultar finalmente a todos. A mí me informaron ese día para evitarme preocupaciones. Se encontró con los doctores Larrey, Ribe y Moreau. Vi que el caso presentaba dificultares singulares o gran riesgo, pero cuando terminaron de examinarme, se retiraron a deliberar entre ellos. Los dejé. ¡Qué media hora pasé yo sola! El señor d'Arblay estaba en su despacho. Entonces, el doctor Larrey vino a llamarme. No me dijo nada, pero parecía mi querido hermano James ${ }^{15}$, cuyo parecido nos ha llamado la atención al señor d'Arblay y a mí. Regresé y me senté con toda la calma que

15. James Burney era hermano de Frances y oficial de la Marina. Había acompañado al Capitán Cook en sus expediciones al Pacífico y escribió obras sobre viajes (A Chronological History of the Discoveries in the South Sea or Pacific Ocean, [Historia cronológica de los descubrimientos en los Mares del Sur y el Océano Pacífico] cinco volúmenes 1803-1817) y A History of the Buccaneers of America [Historia de los bucaneros de América] 1816). Tuvo una relación polémica con Sarah Harriet Burney.

Feminismo/s 39, January 2022, 59-95 
«I often thought if it could not be dissolved, it could only with life be extirpated»: a translemic analysis and Spanish translation of Frances Burney's Letter from Frances Burney to her sister Esther about her mastectomy without anaesthetic, 1812

pude. Todos estaban en silencio y vi que el doctor Larrey se escondió detrás de mi sofá. Mi corazón palpitaba: veía que se esfumaba toda esperanza. Les pedí que hablasen. Entonces el señor Dubois, tras una larga e ininteligible arenga y con cierta perturbación, pronunció mi sentencia. Ahora veía que era inevitable y me abstuve de cualquier otro esfuerzo. Recibieron mi consentimiento formal y se retiraron para fijar un día.

Se acababa toda esperanza de escapar de este mal. Sólo podía consolarme o dedicarme a pensar cómo hacerlo menos terrible para el señor d'Arblay. El señor Dubois había dicho «hay que esperar a sufrir. No la voy a engañar. Sufrirá, ¡sufrirá mucho!» ¡El señor Ribe me había pedido que llorase! Evitarlo o contenerlo podría tener consecuencias serias, dijo. El señor Moreau, al repetir este consejo, me preguntó si había llorado o gritado cuando había nacido Alexander. «Por desgracia», le dije, «no habría sido posible de otro modo». «Oh, entonces no hay nada que temer», respondió. ¡Qué terribles inferencias se extraen de esto! Así que decidí no decir nada al señor d'Arblay hasta que pasase la operación. Estuvieron totalmente de acuerdo, excepto el señor Larrey, al que parecía que no le gustaba la idea, pero estaba callado. El señor Dubois manifestó que no haría nada si veía agitado al señor d'Arblay, en caso de estar presente, y que tampoco me iba a hacer sufrir diciéndome la hora el día antes. Conseguí que me prometiesen avisarme cuatro horas antes, que me eran necesarias para arreglar varios asuntos.

Desde entonces, adopté la actitud más positiva que pude para enfrentarme a las dificultades y apoyar a mi siempre compasivo compañero. No me dejaron hacer ningún preparativo y se negaron a decirme qué haría falta. Luego me he enterado de que la señora de Tessé, una gran amiga del señor d'Arblay y mía y una de las mejores mujeres del mundo por sus extraordinarias habilidades y amplio conocimiento, había insistido en enviarme todo lo necesario y me había mantenido ignorante de ello. El señor d'Arblay llenó un cuarto con telas, compresas y vendajes. Todo lo que me hacía falta era una butaca y unas toallas. Sin embargo, muchas cosas unidas a la profundidad de mi dolor me decían que el asunto comportaba mucho peligro. Por eso hice mi testamento sin decírselo al señor d'Arblay y se lo entregué en privado al señor La Tour Maubourg ${ }^{16}$, incluso sin haberle revelado el secreto a su her-

16. Véase nota 2.

Feminismo/s 39, January 2022, 59-95 
«I often thought if it could not be dissolved, it could only with life be extirpated»: a translemic analysis and Spanish translation of Frances Burney's Letter from Frances Burney to her sister Esther about her mastectomy without anaesthetic, 1812

mana, quien es mi amiga la señora de Maisonneuve. Se lo entregué al señor de Mg para ese excelente amigo de Maria, el señor Gillet, quien me explicó cómo proceder. En cuanto pueda salir, revelaré este asunto clandestino al señor d'Arblay... Hasta entonces, esto podría afectarle.

La señora de Maisonneuve quería estar presente en la operación, pero yo no le infligiría tal dolor. La señora de Chastel, nuera de la señora de Boinville, también aguantaría el susto, pero me aseguré dos guardianas, una a la que conocen mis dos queridas Charlottes, la señora Soubiren, portera del Hotel Marengo, una gran criatura, que a veces me divierte al decir «mu bie Siñora», que me dice que ha aprendido de la joven Charlotte, a la que sólo nombra con emoción. El otro es un trabajador al que he contratado a menudo. El cariño que he recibido durante este tiempo me habría hecho amar Francia, si hasta entonces mi corazón se hubiese endurecido para odiarlo, pero la ternura que me ha demostrado la señora d'Henin sobrepasa toda descripción. Ha venido dos veces a París desde el campo para visitarme, verme y hacerme compañía, y me ha prestado todo tipo de servicios y atenciones. Su dulce corazón me ama y también ama a la señora Lock, de la que dice a menudo «iAh! Si vuestra amiga Angelique estuviese aquí...» Pero debo excusar estos comentarios, que espero que mi queridísima Esther no considerará excesivos.

Dictada la sentencia, estuve esperando la llamada para su ejecución. Juzga, entonces lo que ha sido estar tres semanas en ese estado. El señor Larrey me visitaba de vez en cuando, pero no decía nada y siempre estaba melancólico. Al final le dijeron al propio señor d'Arblay que le avisarían ¡Y de manera formal y por escrito! Yo no podía. El máximo esfuerzo que podía hacer era dar mi consentimiento. Sin embargo, el pobre señor d'Arblay deseaba por escrito que si la operación era necesaria se realizase lo antes posible. En mi mente, me había convencido totalmente de que había esperanzas de curarme, si no era así, ¿por qué demoraban tanto la comunicación de mi condena? Pero aquí debo explicar esta aparentemente inútil y cruel medida, aunque yo sólo me enteré dos meses después.

El señor Dubois había explicado que el mal había avanzado demasiado para poder curarse, que el cáncer se había declarado internamente, que yo estaba destinada para la muerte más horrible y que una operación aceleraría mi fin. El pobre señor Larrey estaba tan afectado por esta sentencia que, como me ha dicho últimamente, lamentaba haberme conocido y estuvo a

Feminismo/s 39, January 2022, 59-95 
«I often thought if it could not be dissolved, it could only with life be extirpated»: a translemic analysis and Spanish translation of Frances Burney's Letter from Frances Burney to her sister Esther about her mastectomy without anaesthetic, 1812

punto de pedir el traslado al otro lado de Francia para que yo estuviese en otras manos. Sin embargo, él recordaba que yo había dicho una vez que preferiría una muerte rápida antes que una vida de padecimientos con esta malísima enfermedad. Finalmente consideró que podría intntar salvarme, que mi caso era desesperado y decidió intentarlo. No obstante, para él era una responsabilidad demasiado grande, por lo que esperaba un aviso formal. En resumen, la última mañana de septiembre de 1811, mientras yo estaba en cama y el señor d'Arblay ordenaba unos papeles en su oficina, recibí una carta del señor de Lally $^{17}$ a un periodista reivindicando la memoria de su padre contra las acusaciones de la señora du Deffand. La leí en voz alta a mis Alexanders con lágrimas de admiración y comprensión y luego se la envié a Alex. A su excelente autor también, como había prometido la noche anterior. Luego me vestí, ayudada, como venía siendo habitual desde hacía varios meses, por mi sirvienta, dado que no podía mover mi brazo derecho. Todavía no había terminado cuando me entregaron otra carta. ¡Otra! Esta era del señor Larrey, para anunciarme que a las 10 estaría conmigo, acompañado de otras personas y para pedirme que confiase tanto en su sentido común y prudencia como en su habilidad y experiencia. Me pidió que le asegurase que no estaría el señor d'Arblay y me dijo que el joven médico que me había llevado esta noticia prepararía la operación, en la que ayudaría, y también que había decidido avisarme sólo dos horas antes.

Juzga, querida Esther, si puedo leer esto sin emocionarme. Sin embargo, debía esconder mis sensaciones e intenciones del señor d'Arblay. El doctor Aumont, el mensajero y horrible emisario, estaba esperando. El señor d'Arblay estaba al lado de mi cama y yo disimulaba estar leyendo la nota a fin de ganar tiempo para decidir algo y tenía tal pavor a involucrar al señor d'Arblay en la desdicha inútil de presenciar lo que yo debía padecer que una cosa pudo con la otra y ambas me dieron fuerza para actuar como si me dirigiese una tercera persona. Los detalles serían demasiado prolijos, como dice James, pero de lo que se trata es de que llamé a Alex al pie de mi cama y le pedí que informase al señor Barbier Neuville, jefe de división del departamento del

17. El político francés de origen aristocrático Trophime-Gérard, Marqués de LallyTollendal (1751-1830), pasó gran parte de su vida defendiendo el honor de su padre, Thomas Arthur de Lally (1702-1766), que había sido ejecutado durante la Revolución.

Feminismo/s 39, January 2022, 59-95 
«I often thought if it could not be dissolved, it could only with life be extirpated»: a translemic analysis and Spanish translation of Frances Burney's Letter from Frances Burney to her sister Esther about her mastectomy without anaesthetic, 1812

señor d'Arblay, de que había llegado el momento, y le pedí que informase de que un asunto urgente requería al señor d'Arblay y estaría ocupado hasta su término. Alex se fue tan mudo y asustado que tuvo que sentarse y lloró al cumplir su cometido. Entonces, a través de la sirvienta mandé recado al joven doctor Aumont de que no estaría preparada hasta la una y terminé mi desayuno y, tú me creerás, sin mucho apetito me tomé una corteza de pan y despisté con varias excusas al señor d'Arblay. Apenas se había ido cuando llegó el señor Dubois: insistí en mi petición de la una. Llegaron todos los demás y consintieron esperar ya que tenía que preparar una habitación para mi compañero huido.

Estos preparativos y los míos propios me tuvieron todo el día ocupada. Hice marchar a dos enfermeras. Tenía una cama, cortinas y Dios sabe qué tenía que preparar, pero estar ocupada era bueno para mis nervios. Me obligaron a salir de mi habitación para ponerla en orden. El doctor Aumont no se iba, estaba en el salón doblando sábanas. Había pedido que hubiera cuatro o cinco sábanas debajo de la ropa. Me deslicé en nuestra biblioteca: varios libros útiles y varios recados consumieron mi tiempo hasta la una. Cuando todo estuvo listo, llegó el doctor Moreau comunicando que el señor Dubois no podría llegar hasta las tres. El doctor Aumont se marchó y ya no había moros en la costa. Realmente esta espera fue horrible. No tenía nada que hacer, no paraba de pensar, así se perdieron dos horas interminables. De buena gana habría escrito a mi queridísimo padre, a ti Esther, a Charlotte James, a Charles, a Amelia Lock, pero mi brazo me lo impedía. Caminé hasta el salón. Al verlo con todos los preparativos, me eché atrás, pero pronto volví: ¿de qué valía esconderme a mí misma algo que pronto conocería? Sin embargo, al ver tal cantidad de vendas, compresas y esponjas me sentí enfermar. Di un paso atrás y otro adelante hasta que me tranquilicé y poco a poco me aturdí. No sentía nada ni tenía conciencia y así me quedé hasta que el reloj dio las tres. Se apoderó de mí un espíritu inquieto, desafié a mi pobre brazo, que ya no valía para nada y cogí la pluma que ya hacía tiempo había abandonado para escribirle unas pocas palabras al señor d'Arblay y unas pocas más a Alex, en caso de que sucediese lo peor. Estos breves documentos sólo los pude guardar cuando los cabriolés (uno, dos, tres y cuatro) empezaron a pararse ante mi puerta. 
«I often thought if it could not be dissolved, it could only with life be extirpated»: a translemic analysis and Spanish translation of Frances Burney's Letter from Frances Burney to her sister Esther about her mastectomy without anaesthetic, 1812

El doctor Moreau entró inmediatamente en mi cuarto para saber si todavía estaba viva. Me dio un poco de vino y se fue al salón. Llamé a mi criada y enfermeras, pero, antes de que pudiese hablar con ellas y sin ningún mensaje previo, entraron siete hombres de negro: doctor Larrey, el señor Dubois, doctor Moreau, doctor Aumont, doctor Ribe y un alumno del doctor Larrey y otro del señor Dubois. Se despertó mi pánico e indignación. ¿Por qué tantos? ¿Y sin permiso? Pero no podía articular una sílaba. El señor Dubois actuaba como Comandante en Jefe, el doctor Larrey se mantenía al margen. El señor Dubois pidió que se pusiese una cama en medio de la habitación. Estupefacta, miré al doctor Larrey, que había prometido que bastaría con un sofá, pero bajó la cabeza y no me miró. Dubois pidió dos colchones viejos y una sábana vieja. Empecé a temblar violentamente, más por la repulsión y el horror de los preparativos que por el dolor.

Cuando todo estuvo como ellos deseaban, me pidieron que subiese a la cama. Me quedé paralizada durante un momento, no sabía si escapar. Miré hacia la puerta, las ventanas, me sentía desesperada, pero fue sólo un momento. Se apoderó de mí la razón y mis miedos y mis sentimientos luchaban contra ella en vano. Llamé a mi criada, quien estaba llorando, y las dos enfermeras estaban absortas en la puerta. "iQue se vayan estas mujeres!» gritó el señor Dubois. Al oír esta orden recobré la voz: «No», grité, «ique se queden, que se queden!». Esto generó una pequeña disputa que me reanimó. Sin embargo, la criada y una de las enfermeras se marcharon y se pidió a la otra que se acercase y obedeció. Ahora el señor Dubois intentaba hacer cumplir sus órdenes en modo militar, pero yo me opuse todo lo que pude. No obstante, me obligaron a quitarme mi larga bata, que yo pretendía conservar. ¡Ah! Entonces, ¡cómo pensaba en mis hermanas! En un momento tan horrible, no tenía a nadie cerca que me protegiese, me colocase, me guardase. Me arrepentí de haber rechazado a la señora de Maisonneuve, la señora Chastel... No había nadie en quien yo pudiese confiar. Mi ángel huido se había marchado ¡Cómo pensaba en ellas! ¡Cómo echaba de menos a mi Esther, a mi Charlotte!

Creo que mi desesperación era aparente, aunque no mis deseos, ya que entonces el propio señor Dubois se suavizó y habló con dulzura. Grité: «¿Puede compadecerse de una operación que, para usted, debe parecer tan trivial?» «¿Trivial?», repitió cogiendo un trozo de papel que rompió en un 
«I often thought if it could not be dissolved, it could only with life be extirpated»: a translemic analysis and Spanish translation of Frances Burney's Letter from Frances Burney to her sister Esther about her mastectomy without anaesthetic, 1812

millón de pedazos. «Si, es poca cosa, pero...» tartamudeó y no pudo continuar. Nadie más podía hablar, pero me relajé al ver que incluso el señor Dubois se ponía nervioso mientras el doctor Larrey se mantenía distante aunque rápidamente vi que estaba tan pálido como la cera. De verdad, yo no sabía el peligro en el que estaba, pero todo me llevaba a pensar que el peligro me rondaba y que sólo este intento me salvaría de sus garras.

Así que subí voluntariamente a la cama y el señor Dubois me puso sobre el colchón y colocó un pañuelo de batista en mi rostro. Sin embargo, era transparente y a través de él vi que la cama era inmediatamente rodeada por los siete hombres y mi enfermera. No quise que me sujetasen, pero entonces, a través de la batista, vi el brillo del acero resplandeciente. Cerré los ojos. No me atreví a mirar la terrible incisión por el miedo que me agitaba. Luego hubo un silencio sepulcral, que duró varios minutos, durante los cuales imaginé que se hacían señas y me examinaban. ¡Oh, qué suspense tan horrible! No respiraba y el señor Dubois intentaba encontrarme el pulso en vano. Al fin, el doctor Larrey, rompió la pausa y con una voz de solemne melancolía dijo: «¿Quién me sujeta este seno?»

No respondió nadie, al menos no verbalmente, pero esto me sacó de mi estado pasivamente sumiso porque temí que pensasen que todo mi pecho se había infectado y no iba mal porque de nuevo a través de la batista vi alzada la mano del señor Dubois mientras su índice describía una línea recta de arriba abajo del pecho, luego una cruz y finalmente un círculo, como si hubiese que sacarlo todo. Desesperada ante esta idea, reaccioné, me quité el velo y al oír «¿Quién me sujeta este seno?» grité «Yo, señor» y lo sujeté con mi mano explicando dónde me dolía, que todo venía de un punto aunque se irradiaba a todas partes. Me escucharon con atención, pero en silencio sepulcral, y el señor Dubois me volvió a colocar como antes y volvió a ponerme el velo sobre el rostro. ¡Oh, lo cuento de una forma vanidosa! Inmediatamente volví a ver al dedo fatal describiendo la cruz y el círculo. Sin esperanza, desesperada y entregada al destino, volví a cerrar los ojos, negándome a ver más, a resistir, a intervenir y tristemente convencida de que sería abandonada.

Mi queridísima Esther y todos a los que quiero tanto y a los que ella contará esta triste cantinela se alegrarán al saber que una vez tomada esta decisión nos adherimos a ella desafiando el terror que sobrepasa toda descripción y el dolor más torturador. Sin embargo, cuando el horrible acero 
«I often thought if it could not be dissolved, it could only with life be extirpated»: a translemic analysis and Spanish translation of Frances Burney's Letter from Frances Burney to her sister Esther about her mastectomy without anaesthetic, 1812

penetró en el pecho cortando venas, arterias, carne y nervios, nadie me mandó que me callase. Comencé a gritar como una loca mientras hicieron la incisión y aún me sorprendo de no tener aquel grito todavía en mis oídos. ¡Qué dolor tan insoportable! Cuando hicieron la herida y retiraron el instrumento, el dolor no cesaba porque el aire que entraba de golpe en esa parte tan delicada parecía una masa de diminutos puñales afilados y dentados que desgarraban los bordes de la herida. Entonces, cuando volví a sentir otra vez el instrumento describiendo la curva, en la dirección contraria, si se puede decir, mientras la carne resistía con fuerza para oponer y cansar la mano del ejecutor, que tenía que cambiar de la derecha a la izquierda, entonces yo sí creí que iba a expirar. Ya no intenté abrir los ojos. Parecían cerrados de manera tan hermética y firme que era como si las pestañas se hubiesen encarnado en las mejillas.

Cuando retiraron el instrumento por segunda vez, creí que ya había terminado la operación. ¡Oh no! Al momento volvieron a cortar y fue más terrible y peor que antes para separar el fondo, la raíz de esta horrible glándula de las partes a las que estaba pegada. De nuevo, toda descripción sería inútil, pero todavía no habíamos terminado. El doctor Larrey sólo descansó su mano y ¡oh Cielos! entonces sentí el cuchillo hurgando en el esternón, arañándolo. Cuando terminó, mientras yo todavía sufría una tortura indescriptible, oí la voz del señor Larrey (todos los demás guardaban silencio sepulcral) en un tono casi trágico preguntar a todos los presentes si faltaba algo por hacer o si la operación había terminado. La opinión de todos era «sí», pero el dedo del señor Dubois, que yo sentía literalmente elevado sobre la herida de tan sensible que estaba, aunque ni yo veía nada ni él tocaba nada, apuntaba a un nuevo requerimiento y de nuevo empezaron a hurgar. Después de esto, el doctor Moreau creyó ver un átomo maligno y una y otra vez, el señor Dubois exigió átomo por átomo. Mi queridísima Esther, no fue durante días ni semanas, sino durante meses que no fui capaz de hablar de este terrible suceso sin volver a revivirlo ¡No podía pensar en él sin impunidad! Estaba enferma, me alteraba ante cualquier pregunta, incluso ahora nueve meses después me duele la cabeza de contarlo. Y no me atrevo a revisar ni a leer este relato miserable que comencé hace al menos tres meses. El recuerdo es todavía muy doloroso. 
«I often thought if it could not be dissolved, it could only with life be extirpated»: a translemic analysis and Spanish translation of Frances Burney's Letter from Frances Burney to her sister Esther about her mastectomy without anaesthetic, 1812

En conclusión, el mal era tan profundo, el caso tan delicado y las precauciones necesarias para evitar una recaída fuerte que la operación, incluyendo el tratamiento y el vendaje, duró 20 minutos. Para un sufrimiento tan agudo, este tiempo era apenas soportable. Sin embargo, lo soporté con todo el coraje que pude y ni me moví, ni les frené, ni me resistí, ni me quejé, ni hablé, excepto una o dos veces durante el vendaje para decir «iAh señores, que yo me queje a ustedes...!» porque de verdad que me daba cuenta de la preocupación compasiva con la que veían todo lo que aguantaba aunque mi discurso se dirigía principalmente, muy principalmente, al doctor Larrey. Salvo esto, no pronuncié ni una sílaba, excepto cuando al poco retomaron su trabajo y grité «iAvísenme, señores, avísenme!».

Creo que me desmayé dos veces; al menos tengo dos lagunas en mis recuerdos del procedimiento que me impiden unificar lo que sucedió. Cuando acabó todo y me levantaron y me pusieron en la cama, estaba tan débil que me tenían que llevar ellos y no podía sostener las manos ni los brazos que me colgaban como si no tuviesen vida mientras mi rostro, como me ha dicho la enfermera, estaba totalmente pálido. Este traslado hizo que abriese los ojos y viese al buen doctor Larrey, casi tan pálido como yo, con el rostro manchado de sangre y una expresión que describía pena, aprensión y casi horror. Cuando estaba en la cama, mi pobre señor d'Arblay, que debería escribirte su propia historia de esta mañana, me vino a ver y después nuestro Alex.

\section{[Letra del Señor d'Arblay]}

¡No! No, mi queridísima y por siempre querida amiga, no correré ningún riesgo. Lo que yo he pasado en el maldito transcurso de esas siete horas no se puede explicar en ninguna lengua. Sin embargo, todos vosotros, mis más queridos amigos, podéis adivinarlo y debéis saberlo. Alexander también ha sufrido mucho, pero ha demostrado más entereza. A lo mejor, él podría describirte mejor, o casi mejor, el estado torturado de mi pobre corazón y mi pobre mente. Además, tengo que reconocer que esos detalles que justo hasta ahora eran bastante desconocidos para mí casi me han matado y sólo puedo agradecer a Dios que este más que medio ángel haya tenido el coraje sublime de negarse el consuelo que yo le podría haber aportado con el fin 
«I often thought if it could not be dissolved, it could only with life be extirpated»: a translemic analysis and Spanish translation of Frances Burney's Letter from Frances Burney to her sister Esther about her mastectomy without anaesthetic, 1812

de ahorrarme el no compartir los dolores atroces. Eso era imposible, pero no el ser testigo de algo tan atroz y tal vez el remordimiento de convertirlo en algo más trágico, ya que debo confesar que no presumo de haberlo podido soportar.

¡Gracias al Cielo! Ahora está sorprendentemente bien y de buen humor y esperamos que vengan muchísimos días buenos. Que pronto lleguen días tranquilos y que me permitan pasarlos con la gente a la que quiero y con mis siempre queridos amigos de la ciudad y la campiña. ¡Amén, amén!

\section{[Letra de Frances Burney]}

Que Dios bendiga a mi queridísima Esther. Temo que esto se haya escrito de forma confusa, pero no puedo leerlo, no puedo escribir más. Por eso, te pido que les dejes leerlo a mis queridos hermanos y hermanas y que también se lo dejes a mi tierna y querida señora Angerstein. Yo sé que ella excusará y yo me excusaré así de tener que escribir una carta sobre el tema. Mi queridísimo padre y mi queridísima señora Lock salen tan poco que me alegro de que nunca oigan esta aventura. De verdad, deseo que nunca llegue a sus oídos. Mi amable señorita Cambridge y la señorita Baker, probablemente tampoco se enterarán. Que se enteren otras personas, lo dejo a decisión tuya.

Debería haber mencionado a Sarah ${ }^{18}$ cuando me lamentaba y suspiraba por mis hermanas, ya que estoy segura de que ella me habría atendido de buena gana y con mucho cariño en todo lo que hubiese podido, pero en ese momento crítico sólo pensé en aquellos que ya me habían mostrado su cariño y ella está muy presente para mí en todo momento aunque que se ha ido para siempre. Adiós, adiós, mi querida Esther.

18. Sarah Harriet Burney era la hermanastra menor de Frances. Destacó como escritora (Clarentine 1796, Geraldine Fauconberg 1808, Traits of Nature [Rasgos de la naturaleza] 1812, Tales of Fancy [Relatos de imaginación] 1816-20 y The Romance of Private Life [El romance de la vida privada] 1839). Desde 1798 a 1803 vivió con su hermano James en Bristol y Londres después de que él se hubiese separado de su esposa, lo que generó un escándalo familiar. Cuando tiene lugar la mastectomía, Sarah Harriet se encontraba viviendo con su padre, a quién cuidó hasta su muerte.

Feminismo/s 39, January 2022, 59-95 